OPEN ACCESS

Edited by:

Kai Fang,

University of California, Los Angeles,

United States

Reviewed by:

Adam Michael Reitzel,

University of North Carolina at

Charlotte, United States

Ka Man Law,

University of California, Los Angeles, United States

*Correspondence:

Chao-Yu Miao

cymiao@smmu.edu.cn

tThese authors have contributed equally to this work.

Specialty section:

This article was submitted to Inflammation,

a section of the journal

Frontiers in Immunology

Received: 07 October 2017

Accepted: 14 November 2017

Published: 28 November 2017

Citation:

Zhang S-L, Wang S-N and Miao C-Y (2017) Influence of Microbiota on

Intestinal Immune System in Ulcerative Colitis and Its Intervention.

Front. Immunol. 8:1674. doi: 10.3389/fimmu.2017.01674

\section{Influence of Microbiota on Intestinal Immune System in Ulcerative Colitis and Its Intervention}

\author{
Sai-Long Zhang ${ }^{\dagger}$, Shu-Na Wang ${ }^{\dagger}$ and Chao-Yu Miao* \\ Department of Pharmacology, Second Military Medical University, Shanghai, China
}

Ulcerative colitis $(\mathrm{UC})$ is an inflammatory bowel disease (IBD) with chronic and recurrent characteristics caused by multiple reasons. Although the pathogenic factors have not been clarified yet, recent studies have demonstrated that intestinal microbiota plays a major role in UC, especially in the immune system. This review focuses on the description of several major microbiota communities that affect UC and their interactions with the host. In this review, eight kinds of microbiota that are highly related to IBD, including Faecalibacterium prausnitzii, Clostridium clusters IV and XIVa, Bacteroides, Roseburia species, Eubacterium rectale, Escherichia coli, Fusobacterium, and Candida albicans are demonstrated on the changes in amount and roles in the onset and progression of IBD. In addition, potential therapeutic targets for UC involved in the regulation of microbiota, including NLRPs, vitamin D receptor as well as secreted proteins, are discussed in this review.

Keywords: intestinal microbiota, host immune response, ulcerative colitis, epithelial cells, therapeutic targets

\section{INTRODUCTION}

Ulcerative colitis (UC) is a sort of chronic recurrent disorder with the characteristics of intestinal mucosa inflammation and ulceration (1-3). The disease causes significant morbidity worldwide, with morbidity and prevalence increasing over time (4). UC is also regarded as a polygenic and multiple diseases caused by a series of complex factors such as environment, genes, and immunomodulatory factors (5).

The microenvironment of the gut forms a good microbiota habitat, which has been demonstrated to affect many physiological conditions in earlier studies (6-8). Since intestinal microbiota is considered as an important organ of the human body in recent times, an increasing number of studies have linked this microenvironment to gastrointestinal diseases. Because the composition of the intestinal microbiota is stable over a period of time, many studies inferred the gut microbiota as a potential predictor of health status and a target for therapeutic intervention (9). Moreover, it has been report that intestinal microbiota has a key role in inflammatory bowel disease (IBD), including UC and Crohn's disease (CD) (10). Considering the complexity and diversity of the human gut microbiota, there is no denying that it is difficult to demonstrate the presence of specific bacterial strains, which play a certain role in the pathogenic mechanism of IBD. Unlike the well-researched CD, our knowledge on UC is relatively deficit, and there remain many contradictions to be elucidated.

In this review, the relationship between UC and several popular microbiota communities highly related as well as the potential therapeutic targets for UC involved in the regulation of microbiota will be discussed. 


\section{PART I: MICROBIOTA}

The colon has two mucus layers, which is different from the small intestine with a single layer of mucus. The inner layer is a mucous lining that is closely linked to the intestinal epithelium, which provides a sterile environment. Outer layer is a mucous layer of varying thickness, composed of mucins, trefoil peptides, and secretory $\operatorname{IgA}(11,12)$. Although there is bidirectional effects between the microbiota and the host, its direct effects on intestinal epithelial cells are limited by mucus layers and antimicrobial peptides (AMPs) such as defensins and regenerating islet-derived 3 gamma (Reg3g) $(7,13,14)$. The healthy and complete mucus layer only enables intestinal microbiota to attach to the mucus layer instead of the direct touch of intestinal epithelial cells. There are four phyla of microbiota in normal human intestine including Bacteroidetes, Firmicutes, Actinobacteria, and Proteobacteria, two of which (Bacteroidetes and Firmicutes) are dominant in the gut (15-17). In the intestinal tract of healthy people, Firmicutes, a community of Gram-positive bacteria, are classified into two main groups: Bacilli and Clostridia (primarily Clostridium cluster IV and Clostridium XIVa). The Gram-negative Bacteroidetes resides in the gut as one of the most abundant genera. And some studies have shown that these four groups are relatively stable in healthy people $(9,18)$. Here, in this section, we focus on the description of the microbiota which are closely related to the pathogenesis and progression of UC (summarized in Table $\mathbf{1}$ and Figure 1).

\section{Faecalibacterium prausnitzii}

The F. prausnitzii is one of the richest species. There are large population of $F$. prausnitzii bacteria in the normal human body, occupying 6-8\%, even $20 \%$ among all kinds of microbiota $(17,19-23)$. Some studies reported it as one of the main producers of a short-chain fatty acid (SCFA) called butyrate in the intestine.
SCFA has an anti-inflammatory effect that results from the production of regulatory $\mathrm{T}$ (Treg) cells and the energy supply of intestinal epithelial cells $(24,25)$. In addition, it (SCFA) also exerts anti-inflammatory effects through upregulating the antiinflammatory cytokines secretion such as IL-10 $(26,27)$. It was further reported that the anti-inflammatory effects are partially related to their disruption of NF- $\kappa \mathrm{B}$ activation, blocking IL- 8 production $(28,29)$. Based on those previous studies, F. prausnitzii plays an important role in the protection of colonic functions through its anti-inflammatory mechanisms.

In recent studies, $F$. prausnitzii has been demonstrated to involve in the maintenance of intestinal health $(26,29-46)$. Of note, some studies have shown that there is a significant difference in F. prausnitzii between healthy people and UC patients (30, 31, 33-38, 41, 46). Compared with healthy people, $F$. prausnitzii species had lower counts in UC patients (30-35, 38, 40-44). For instance, Machiels et al. introduced real-time PCR analysis to find that F. prausnitzii in UC patients had a lower abundance than health people. They also demonstrated an inverse correlation with disease activity (46). Furthermore, Varela et al. found that less than 12 months of remission and more than one relapse/year were linked with low counts of F. prausnitzii. And the recovery of the F. prausnitzii population after relapse has connection with clinical remission maintenance (42). In fact, phylogenetic analysis showed that there were at least two subtypes of $F$. prausnitzii, with differences in the distribution of subtypes among people with gut disorders and healthy subjects $(32,39)$. Phylogroup I was accounted for $87 \%$ in healthy subjects while under $50 \%$ in IBD patients. By contrast, phylogroup II was found in IBD patients with $>75 \%$, while only $52 \%$ in healthy subjects. This study reveals that even though the majority of the F.prausnitzii population exists in both healthy subjects and gut diseases individuals, the latter has a reduced richness and an altered phylotype distribution

TABLE 1 | Changes of potential beneficial and harmful microbiota in UC.

\begin{tabular}{|c|c|c|c|}
\hline & Changes in UC & Mechanisms & Reference \\
\hline \multicolumn{4}{|l|}{ Beneficial microbiota } \\
\hline Faecalibacterium prausnitzii & $\downarrow$ & Enhancing production of Treg cells, energy supply of intestinal epithelial cells and IL-10 & $(30-35,38,40-44)$ \\
\hline Clostridium clusters IV and XIVa & $\downarrow$ & Producing butyrate & $(34,43-45,58)$ \\
\hline Bifidobacterium & $\downarrow$ & Inhibiting intestinal inflammation by acting on Treg cells & $(101,102)$ \\
\hline \multirow[t]{2}{*}{ Bacteroides } & $\downarrow$ & Inducing $\mathrm{CD}^{+}$cells by enhancing IL-10 and IL-17 through secreting PSA & $(69,70)$ \\
\hline & $\uparrow$ & Invade intestinal tissues and cause damage & $(67)$ \\
\hline \multirow[t]{2}{*}{ Helicobacter pylori } & $\downarrow$ & 5-ASA and antibiotics & $(105-108)$ \\
\hline & $\uparrow$ & Epidemiological data showed no significant correlation & $(109,110)$ \\
\hline Roseburia species & $\downarrow$ & Producing butyrate & $(44,46)$ \\
\hline Eubacterium rectale & $\downarrow$ & Unknown & $(33,44)$ \\
\hline \multicolumn{4}{|l|}{ Harmful microbiota } \\
\hline \multirow[t]{2}{*}{ Escherichia coli (adherent invasive) } & $\uparrow$ & Invading intestinal epithelial cells, replicating in macrophages and inducing granulomas & $(21,94-97)$ \\
\hline & - & Inactive UC patients & $(87,88,93)$ \\
\hline Fusobacterium & $\uparrow$ & Unknown & $(38,112-116)$ \\
\hline Listeria monocytogenes & $?$ & Unknown & $(117,118)$ \\
\hline Candida albicans & $\uparrow$ & Unknown & $(119,120)$ \\
\hline
\end{tabular}

PSA, polysaccharide A; UC, ulcerative colitis; Treg, regulatory $T$.

$\downarrow$, Decrease; $\uparrow$, increase; —, unchange; ?, to be determined. 


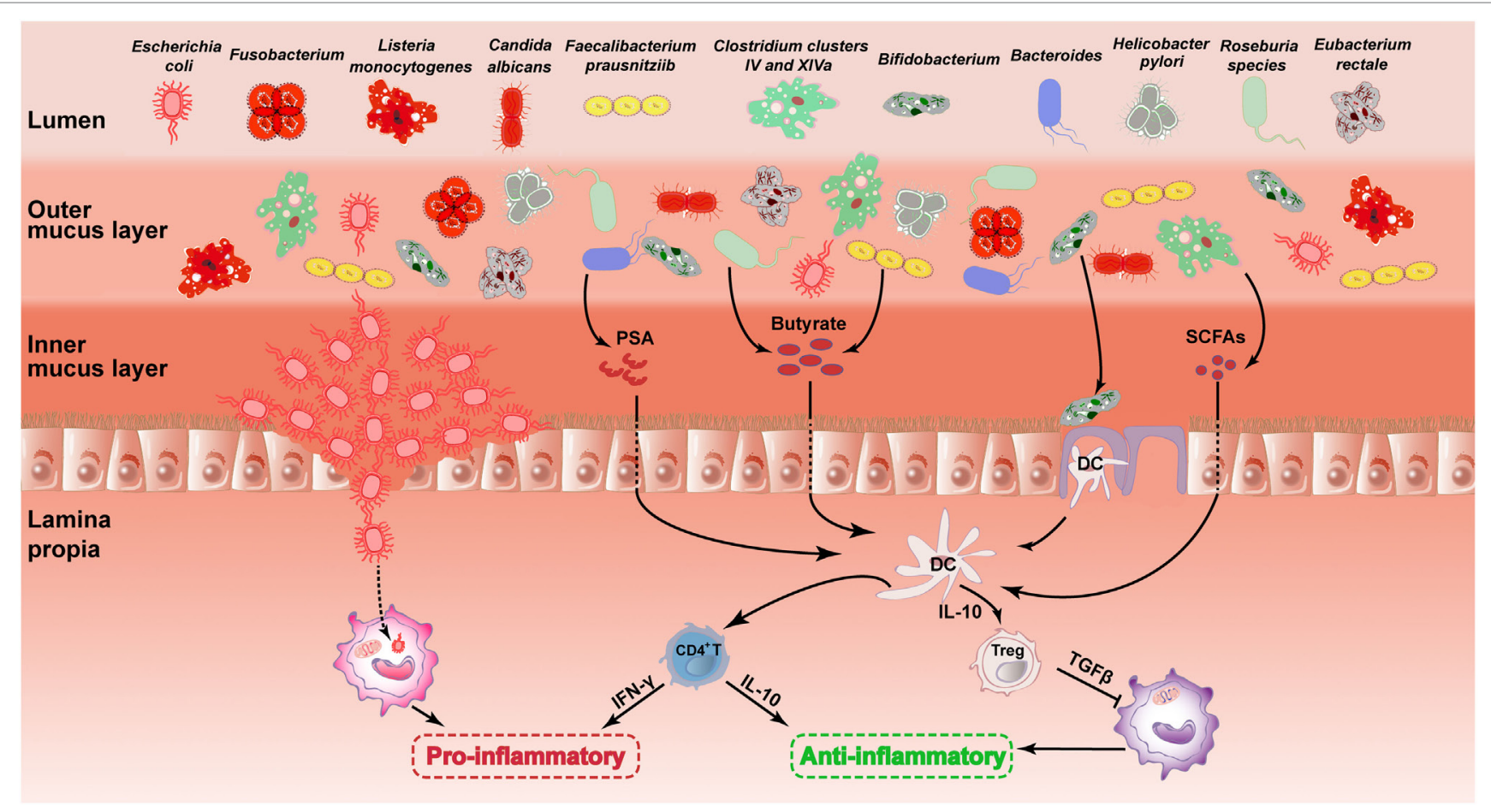

FIGURE 1 | Role of the gut microbiota in the pathogenesis of UC. The picture describes the changes in the major intestinal microbiota in the UC and its influence on gastrointestinal. This illustration contains 11 types of intestinal microbiota and their changes mentioned in this review. The mechanisms underlying the effects of certain microbiota on the gastrointestinal are described. It includes microbiota acting on DC cells by secreting substances such as PSA, butyrate and SCFAs. Then, DC cells further act on CD4+ $T$ cells or regulatory $T$ (Treg) cells to inhibit inflammation. There are also mechanisms by which AlEC destroys the gut barrier and further induces inflammation. The first four species of microbiota are painted in dark red, representing harmful microbiota. The other seven species of microbiota are painted in other colors, representing healthy microbiota. UC, ulcerative colitis; DC, dendritic cell; PSA, polysaccharide A; SCFA, short-chain fatty acid; AIEC, adherent-invasive Escherichia coli.

exists among diseases (39). So far, it is unknown whether there are any other subtypes within the species or other Faecalibacterium species. Besides the researches in patients, there are also some studies in experimental data. For instance, Martín et al. reported that administration of $F$. prausnitzii led to a significant decrease in IBD severity in both severe and moderate chronic colitis models. They also demonstrated that this kind of microbiota could prevent physiological damage in a chronic low-grade inflammation murine model $(47,48)$. Furthermore, Zhang et al. found that F. prausnitzii inhibits interleukin-17 to ameliorate colorectal colitis in rat (49).

Although some studies have shown the characteristics of $F$. prausnitzii, the influential factors of $F$. prausnitzii still remain to be unclarified. For instance, treatment with mesalazine and immunosuppressive agents did not restore the number of F. prausnitzii (37). On the contrary, it was also reported that the plenty of F. prausnitzii was increased in time of induction therapy in patients (36).

\section{Clostridium}

Clostridium is a community of Gram-positive bacteria, which includes several significant human pathogens such as the causative agent of botulism and an important cause of diarrhea, Clostridium difficile. Clostridium species normally inhabit in animal and human soil and intestinal tract. It also exists as a normal resident in the healthy lower reproductive tract of women (50). There are three major species (C. difficile, Clostridium coccoides, and Clostridium leptum) of Clostridium species related to UC.

As a Gram-positive bacterium, C. difficile could produce toxins and cause colitis, especially in patients with antibiotic treatment, resulting in the destruction of commensal microbiota $(51,52)$. Toxins secreted by $C$. difficile can lead to a severe effect on intestinal mucosa. Of note, it has been reported that Clostridium difficile infection (CDI) led to the damage of intestinal barrier through the secretion of exotoxin (53). CDI has risen sharply in the past two decades. IBD patients are more likely to be infected with $C$. difficile because of immunosuppression and dysbiosis in vivo (54-56). Singh et al. showed that individuals with IBD had a 4.8 -fold increase in risk of CDI than individuals without IBD and there is no difference between individuals with UC vs. CD (55). Interestingly, Mabardy et al. reported a decrease of mortality for IBD and non-IBD patients with $C$. difficile but a greater decrease in mortality for IBD patients (54). The incidence and severity of IBD associated with CDI are significant, especially in UC patients with colonic involvement, where the probability of surgery is $20 \%$ (57). Notably, C. difficile has been discussed to cause the relapse of IBD (58). The main problem raised by the 
current study is that CDI is produced after antibiotic treatment $(59,60)$. UC patients may have a higher risk of infection with C. difficile because of antibiotics and immunomodulatory drugs. However, it is worth mentioning that, in addition to the potential pathogenicity of $C$. difficile, there is no direct evidence that C. difficile can cause UC.

On the contrary, the other two Clostridium species are C. coccoides (also called Clostridium clusters XIVa) and C. leptum (namely, Clostridium clusters IV), which appears to be credible factor related to UC $(34,43,44)$. Clostridium clusters IV and XIVa were demonstrated to play a significant role in maintaining intestinal function by producing butyrate $(45,61)$. Furthermore, it was reported that those two microbiota were reduced in the occurrence of UC, suggesting a potential therapeutic target in the treatment of UC $(43,44)$. For instance, C. leptum was reported to induce murine tolerogenic dendritic cells (DCs) and Treg cells in vitro while disrupting the immune inflammatory response (62).

\section{Bacteroides}

Bacteroides are a genus of Gram-negative, obligate anaerobic bacteria, which are important components of the mammalian gut commensal bacteria. Bacteroides species are non-endosporeforming bacilli and may be either motile or non-motile depending on the species of the host. Bacteroides species are usually genetically diverse and constitute the dominant microbiota in the mammalian gastrointestinal tract, playing a fundamental role in processing complex molecules in the host gut to simple molecules $(63,64)$.

The bacteria can exert its beneficial effects on the host by immune regulation and maintenance of homeostasis. It was reported that UC showed an increase of the number of Bacteroides fragilis, which could enhance the mRNA expression of anti-inflammationrelated cytokines such as IL-10, through the secretion of polysaccharide A (PSA) (65-68). Colonized B. fragilis can reverse CD4 ${ }^{+}$ T-cell defects and Th1/Th2 imbalance in germ-free mice (65). Furthermore, it was suggest that $B$. fragilis could protect from experimental colitis, possibly by inducing $\mathrm{CD}^{+}{ }^{+}$cells via IL-10 $(69,70)$. For instance, Round et al. reported that $B$. fragilis directed Foxp $3^{+}$Tregs development and germ-free animal monocolonization by augmenting the suppressive capacity of Tregs and inducing the anti-inflammatory cytokines production solely from Foxp $3^{+}$ $\mathrm{T}$ cells in the gut (70). Besides those researches conducted on patients, experimental data were obtained in animal models. For instance, there has been reported that $I l 10^{-/-}$mice had increased proportions of Bacteroides species (71). In addition, Okayasu et al. found that the amount of Bacteroides was significantly increased in mice with acute and chronic UC (72).

Based on the above evidence, we believe that B. fragilis is critical for maintaining a healthy physiological state of the host. However, B. fragilis is not entirely beneficial in UC. Contrary to previous reports, it was reported to invade intestinal tissues and cause damage in individual patients (73). In addition, other genera of Bacteroides (Bacteroides vulgatus and Bacteroides ovatus) were also found to influence IBD progression (74-80).

\section{Escherichia coli}

Escherichia coli, usually found in the lower intestine of warmblooded organisms, belongs to the family of Enterobacteriaceae (a large family of Gram-negative bacteria that includes many harmful species). As a commensal bacterium widely found in vertebrates, it infected many people each year through intraintestinal and extraintestinal pathways and was reported to kill more than two million humans per year (81). Because E. coli can be transmitted in water and sediment, it is often used as a test indicator of water pollution. The temperature and nutrients in these environments can support the viability of saprophytic E. coli $(82,83)$.

It has been reported that the number of $E$. coli is elevated in UC, whether in mouse models or UC patients $(21,84-89)$. For instance, the number of $E$. coli at the inflammatory sites of UC patients showed a significant increase compared with the control group. Meanwhile, comparative analysis method was introduced to analysis the restriction patterns of $E$. coli isolated from inflammatory and unchanged tissues, respectively. Those results showed that the local inflammatory change did not promote specific strains of E. coli (87). Siczek et al. also demonstrated that administration of NanoAg2 could reduce the number of E. coli alleviating colitis in experimental models of UC (90). Some other reports, however, showed that the number of E. coli did not rise significantly compared with healthy controls $(41,91,92)$. Considering the increased number of $E$. coli has connection with the activity status of UC patients, the difference in the severity of UC may account for the reason. For instance, more abundant of $E$. coli were found in active UC patients than in inactive UC patients or healthy people $(87,88,93)$.

Escherichia coli from ileal CD patients, particularly adherentinvasive Escherichia coli (AIEC) strains, have been reported to be enriched in UC patients $(94,95)$. The concentration of $E$. coli in mucosal sample is larger than that in fecal sample (96). The invasive ability of AIEC strains allows bacteria to move through the human intestinal barrier to the deep tissues. Furthermore, AIEC is able to invade intestinal epithelial cells, replicate in macrophages and induce granulomas in vitro (97). AIEC adheres to an $\mathrm{N}$-glycosylated chitinase 3-like-1 on IECs via the chitin-binding domain of chiA promoting the pathogenic effects of AIEC in mice with colitis (98). The number of AIEC can affect the course of the disease. In addition, mesalazine, an anti-inflammatory drug, can decrease the number of AIEC and relieve inflammation in patients with IBD (99). Therefore, mesalazine might serve as a potential therapeutic strategy in the treatment of UC caused by AIEC infection.

\section{Others}

Bifidobacterium, a community of anaerobic Gram-positive genus, is everywhere in the intestine (100). Bifidobacterium is widely used as one of probiotics, and studies have demonstrated that it plays a significant role in the UC treatment. It was demonstrated that oral administration of Bifidobacterium could block intestinal inflammation by acting on $\operatorname{Tr} 1$ cells, leading to the production of IL-10, thereby ameliorating colitis in immunocompromised mice $(101,102)$. However, so far, since we have little knowledge on the relationship between Bifidobacterium and UC, further studies are demanded on this issue.

Helicobacter pylori is found in the gastrointestinal tract, characterized by its microaerophilic metabolism and spiral shape $(103,104)$. Although H. pylori is widespread in the epithelium of 
the stomach, studies have shown that it can also be detected in the colon and fecal in UC patients (105-108). The relationship between UC and H. pylori is contradictory and complex. For example, it was demonstrated by Engler et al. (109) that infection or treatment with $H$. pylori significantly alleviated the severity of DSS-induced chronic colitis as well as T-cell transfer-induced colitis both in clinical symptom and histopathological features, indicating the protective role of $H$. pylori in UC. However, some epidemiological data showed that there was no significant correlation between $H$. pylori and UC $(110,111)$. Thus, future studies are needed to distinguish between a true protective role of H. pylori and the outcome of UC.

Fusobacterium species are anaerobic Gram-negative bacteria, which are members of the normal microbiota of the oral and intestinal tract. However, certain species of Fusobacterium, such as adherent, invasive, pro-inflammatory species, were identified as UC pathogens $(38,112,113)$. The relative abundance of Fusobacterium in the colonic mucosa of mouse colitis models or IBD patients is increased, among which $69 \%$ of all IBD patients-derived Fusobacterium were identified as Fusobacterium nucleatum (114-116). Moreover, commensal bacteria, including Fusobacterium varium that was one of mucosal organisms isolated from UC patients, were found as a possible pathogen in UC $(112,113)$.

Apart from those above microbiota, there are some other species relate to the pathogenesis and progression of UC, including Roseburia hominis, Eubacterium rectale, Listeria monocytogenes, and Candida albicans (33, 35, 44, 46, 117-120). For instance, in UC patients, $R$. hominis, a well-known kind of Firmicutes phylum bacteria that produces butyrate, differs from that of healthy individuals in number $(44,46)$. E. rectale was reported to be significantly reduced in abundance $(33,44)$, especially in pediatric UC (35). The Gram-positive L. monocytogenes is an intracellular pathogen and is often transmitted to other sites. In recent years, studies have found that it may exacerbate the severity of UC (117). However, in UC endoscopic biopsy samples, it was shown that the number of $L$. monocytogenes did not differ from the normal group. As a result, it does not stand by the direct action for L. monocytogenes in the IBD pathogenesis (118). C. albicans is most often isolated in $91.7 \%$ patients in UC and can delay healing of UC $(119,120)$.

\section{PART II: POTENTIAL TARGETS FOR UC THERAPY}

In the above contents, the roles and changes of several kinds of microbiota in UC have been fully discussed in above contents. Since intestinal microbiota are important in the onset and development of IBD, searching for new intervention targeting microbiota may have potential therapeutic implications for the treatment of UC. It has been reported that interventions such as NLRPs and vitamin D receptor (VDR) may affect the pathogenesis and progression of UC through regulating the composition of microbiota. In addition, several kinds of secreted proteins have been demonstrated to serve as potential therapeutic targets for UC. In this section, we will focus on recent studies on the targets of microbiota, which might be potential therapeutic strategies in the treatment of UC (illustrated in Figure 2).

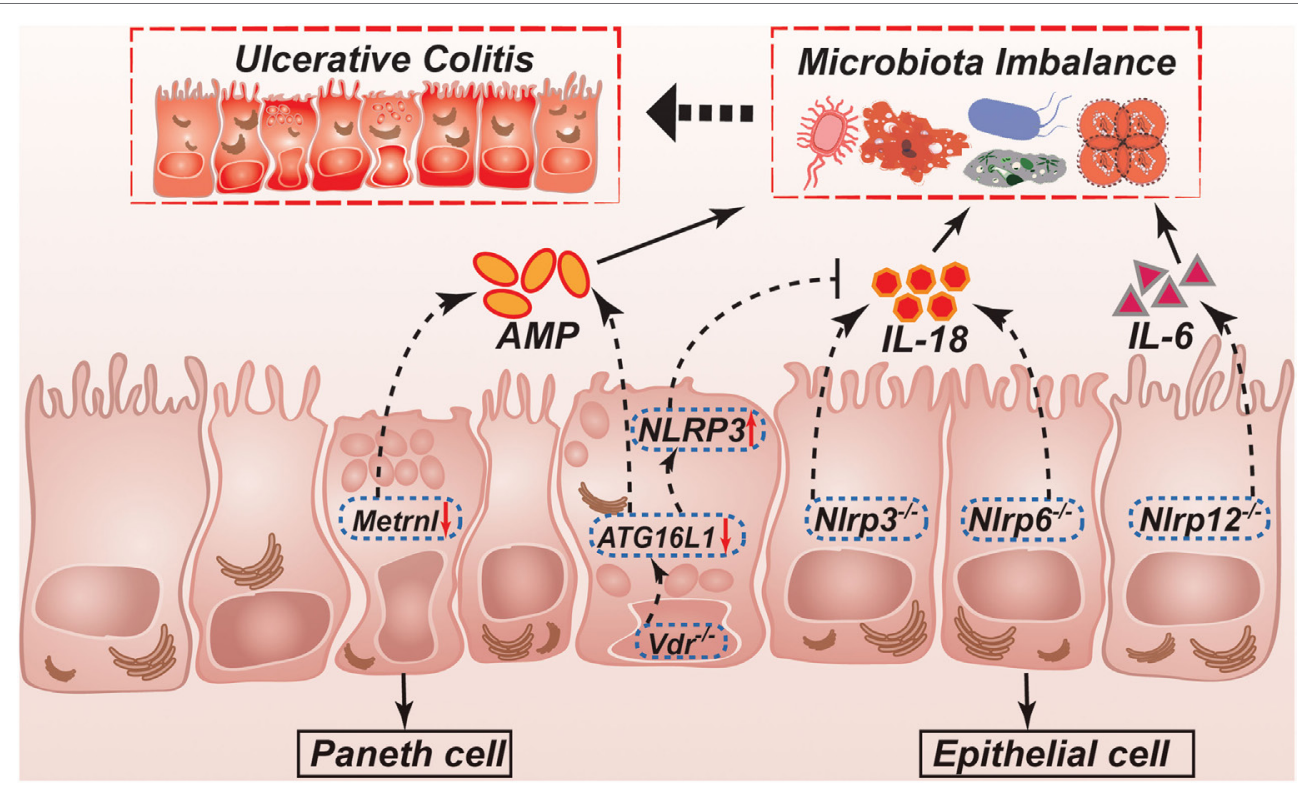

FIGURE 2 | Possible mechanisms controlled by NLRPs, VDR, and Metrnl in regulation of intestinal homeostasis and ulcerative colitis. NLRP3 and NLRP6 inflammasomes regulate secretion of IL-1 $\beta$ and IL-18. IL-18 helps to maintain a non-pathogenic gut microflora, which promote a healthy gut environment. IL-18 is not produced in $\mathrm{NIrp3}^{-/-}$or N/rp6 ${ }^{-/-}$mice, leading to the development of potentially pathogenic species. N/rp12 ${ }^{-/-}$mice results in a more inflammatory environment caused by higher production of cytokines such as IL-1 $\beta$ and IL-6. ATG16L1 is decreased in Vdr-/- mice, which leading to reduction of AMP. Furthermore, ATG16L1 decreasing can also inhibit IL-18 production through upregulating NLRP3 expression. In the intestinal epithelial cell-specific Metrnl knockout mice, reduction of AMP leading to microbiota imbalance. NLRP, NLR family, pyrin domain-containing; VDR, vitamin D receptor; AMP, antimicrobial peptide. 


\section{NLRPs}

NOD-like receptor (NLR) family is one of the important groups of PRRs in IBD. The number of NLRs variety in human and mice are 22 and 30, respectively (121). They are characterized by central nucleotide binding and oligomerization domain. NLRPs (NLR family, pyrin domain containing) can activate caspase-1 and start the inflammatory process (122).

The NLRP3 inflammasome is the most clarified inflammasome and has been reported to further affect disease progression in UC by influencing microbiota (123). Previous reports showed the changes in the number and composition of microbiota in $\mathrm{Nlrp3}^{-{ }^{--}}$ mice. $\mathrm{Nlpp}^{-/-}$mice have been reported to have larger number of microbiota in colon than the wild-type mice (124). Hirota et al. showed that the number of Firmicutes and Proteobacteria are increased in the colon from Nlrp3 $3^{-/-}$mice compared with the wild-type group (125). Although Nlrp $3^{-/-}$mice were demonstrated to be highly susceptible to DSS-induced UC in several studies, one study put forward the contrary results proving that deficiency of the NLRP3 inflammasome protected mice against DSS (124-127). Therefore, further efforts are demanded in the determination of the effects and mechanisms of the NLRP3 inflammasome in UC so that we are able to take advantage of the NLRP3 inflammasome in the treatment of UC in the future.

The expression of the NLRP6 inflammasome can be detected in both the large intestine and the small intestine. It was reported that $\mathrm{Nlrp}^{-/-}$mice more susceptible to UC induced by DSS with tissue injury, bleeding, and increased permeability of the gut epithelium $(126,128)$. It was supposed that the changes in microbiota population of these mice might result from aberrant host-pathogen interactions at this site (129).

The NLRP12 inflammasome has also been found to be participated in the inflammatory process of the colon, especially the protective role in acute colitis. Nlrp12 $2^{-/-}$mice exhibited more severity in colitis upon DSS administration than wild-type mice $(130,131)$. For instance, Zaki et al. showed that $N \operatorname{lrp} 12^{-/-}$mice were highly vulnerable to colon inflammation, indicating the connection with increased production of inflammatory cytokines including IL- $1 \beta$ and IL- 6 . Those effects were led to by the activation of inflammation-related pathways such as NF- $\mathrm{\kappa B}$ and ERK signals in colonic macrophages.

The current major problem is that we have not yet been able to figure out its downstream mediators of the NLRPs and their inflammasomes. It is not clear which factors mediate the effects and whether the observed results are related to a specific microbiota or a combination thereof.

\section{Vitamin D Receptor}

Vitamin D is a group of lipid-soluble steroid substances that promotes the absorption of calcium and magnesium ions. Besides, it has various biological effects, including depression, cardiovascular disease and cancer (132-134). The VDR as a nuclear receptor of vitamin D plays an important role in regulating intestinal microbiota homeostasis and commensal bacteria living environment (135-139). It has been reported that VDR signaling pathway abnormalities and low expression are related to UC (140-143).

Vitamin D can not only regulate the immune response to intestinal microbiota but also change the composition of microbiota
$(144,145)$. For instance, using genome-wide association analysis, two cohort studies showed that the variation of $V d r$ gene in the host could affect the intestinal microbiota through the measurement of selected bile and fatty acids in humans (146). Chen et al. reported that the levels of Eubacterium, Bacteroides, and Salmonella were significantly different between $\mathrm{Vdr}^{-1-}$ and wildtype mice (147). It was also demonstrated in another study that the number of Firmicutes was decreased and that of Bacteroides and Proteobacteria were increased in the fecals in $\mathrm{Vdr}^{-1-}$ mice (144). Jahani et al. showed that vitamin D deficiency at birth caused lower number of colonic Bacteroides and Prevotella later in life (148). Moreover, $V d r$-deficient mice would cause bacterial imbalance, such as depletion of Lactobacillus, as well as enrichment of Clostridium and Bacteroides. In addition, those changes might lead to alterations in some important pathways and further cause other diseases (149). Interestingly, giving vitamin D could lead to an increased number of colon Citrobacter rodentium through inhibiting the Th17 response (150). Remarkably, the lack of vitamin D diet could cause intestinal barrier dysfunction, which substantially made the body more susceptible to infection by intestinal microbiota (151). Similarly, immune changes might cause Vdr-deficient mice to become more sensitive to nonpathogenic bacteria and increase sensitivity to Salmonella-induced colitis inflammation $(152,153)$. Moreover, lacking $V d r$ will cause dysbiosis and resistance to colonization by C. rodentium through strengthening IL-22-producing innate lymphoid cells (154).

So far, although the positive effects of vitamin D system have been proven on the regulation of intestinal microbiota in animal studies, the evidence of those positive effects in human experiment were deficient in the UC patients. Thus, to ultimately take advantage of intestinal microbiota in the treatment of UC, further basic researches and clinical studies should be conducted on this issue.

\section{Secreted Proteins}

Secreted proteins belong to a large family which can be secreted by a cell whether in an endocrine or exocrine manner. Among all of the secreted proteins, cytokines are the most studied proteins. Since first reported in 1965, cytokines were regarded as loose and broad proteins with molecular weight of 5-20 kDa and was demonstrated to play vital roles in the cellular activity (155). As we discussed earlier, several kinds of microbiota could affect intestinal barrier status through regulating the secretion of various kinds of cytokines, thus producing effects on the pathogenesis and progression of UC. For instance, F. prausnitzii could upregulate the production and secretion of IL-10 while inhibiting the secretion of IL-8 $(26,27,29)$. In addition, Bacteroides and Bifidobacterium were reported to act on DCs to regulate the levels of IFN- $\gamma$ and TGF- $\beta$ secreted from CD4 $4^{+} \mathrm{T}$ cells and Treg cells (156). Of note recent studies have reported that several kinds of cytokines, such as IL-1 $\beta$ and IL-10, have an impact on intestinal microbiota and subsequently led to the regulation of UC $(157,158)$. It was demonstrated that interferon- $\beta$, an NLRP3 inflammasome inhibitor and its secretion of IL- $1 \beta$ and IL-18, contributed to the amelioration of gut inflammation and maintenance of gut homeostasis (159). Taken together, taking advantage of targeting to those cytokines might become a potentially effective therapeutic strategy in the UC treatment. 
Beside cytokines, another kind of important secreted proteins regulating the gut homeostasis is adipokine, which are secreted by adipocyte. For example, Metrnl, one of the adipokines, has been reported by studies in our lab which showed a potential regulatory effect on the pathogenesis and development of UC. Metrnl belongs to a secreted protein containing 311 amino acids. It has a similar function to its only homologous gene, Meteorin (Metrn), which is a novel neurotrophic factor (160, 161). Recombinant Metrnl protein can accelerate neuroblast migration in vitro and display a neuroprotective effect in vivo (162). A previous study in our lab identified Metrnl as a novel adipokine during a process to screen new adipokines, demonstrating that Metrnl was abundant in the subcutaneous adipose tissue in both humans and mice $(163,164)$. Meanwhile, we found that Metrnl had higher expression in the human gastrointestinal tract, specifically expressed in the intestinal epithelium (165). Consistently, the mRNA of Metrnl in the mouse gastrointestinal tract also had the highest expression among the tested 14 types of tissues. In the intestinal epithelial cell-specific Metrnl knockout mice, the Metrnl level in the gut fluid were significantly reduced, whereas the Metrnl level in the serum showed a decreasing tendency with no statistical significance. The cell-specific Metrnl deletion did not affect physiological conditions of body weight, food intake, blood glucose, colon length and histology, intestinal permeability, mucus content, or mucin 2 expression but significantly decreased AMPs expression, such as Reg3g and lactotransferrin (165). As AMPs are closely related to microbiota balance, Metrnl may become a potential target for UC treatment. However, developing the related treatment is still a long way to go.

\section{CONCLUSION AND PERSPECTIVES}

So far, different genera of microbiota have been described. It is widely acknowledged that intestinal microbiota plays a

\section{REFERENCES}

1. Head KA, Jurenka JS. Inflammatory bowel disease part 1: ulcerative colitis pathophysiology and conventional and alternative treatment options. Altern Med Rev (2003) 8:247-83.

2. Ford AC, Moayyedi P, Hanauer SB. Ulcerative colitis. BMJ (2013) 346:f432. doi:10.1136/bmj.f432

3. Ungaro R, Mehandru S, Allen PB, Peyrin-Biroulet L, Colombel JF. Ulcerative colitis. Lancet (2017) 389:1756-70. doi:10.1016/s0140-6736(16)32126-2

4. Molodecky NA, Soon IS, Rabi DM, Ghali WA, Ferris M, Chernoff G, et al. Increasing incidence and prevalence of the inflammatory bowel diseases with time, based on systematic review. Gastroenterology (2012) 142:46-54.e42; quiz e30. doi:10.1053/j.gastro.2011.10.001

5. de Souza HSP. Etiopathogenesis of inflammatory bowel disease: today and tomorrow. Curr Opin Gastroenterol (2017) 33:222-9. doi:10.1097/mog. 0000000000000364

6. Marchesi J, Shanahan F. The normal intestinal microbiota. Curr Opin Infect Dis (2007) 20:508-13. doi:10.1097/QCO.0b013e3282a56a99

7. Hooper LV, Littman DR, Macpherson AJ. Interactions between the microbiota and the immune system. Science (2012) 336:1268-73. doi:10.1126/ science. 1223490

8. Turnbaugh PJ, Hamady M, Yatsunenko T, Cantarel BL, Duncan A, Ley RE, et al. A core gut microbiome in obese and lean twins. Nature (2009) 457:480-4. doi:10.1038/nature 07540 significant role in the pathogenesis and progression of UC. It has been reported that certain single microbiota or a combination of individual microbiota may serve as the one of the causes of UC. Furthermore, more and more studies have shown that there is a high prevalence of certain bacterial species in UC patients. However, our understanding on the pathogenicity of the individual microbiota and the human host is still limited. So far, none of the bacteria have been specifically shown to be the direct cause of UC because the majority of the related studies were conducted only after the onset of disease. As we discussed earlier, several strategic targets for UC involved in microbiota were reported taking advantage of their anti-inflammatory effects. However, the mechanisms underlying the treatment of bacterial populations in specific hosts are not very clear, or that molecular targets are not specific. Studies have shown that restoring balance between the host and microbiota can reduce the incidence of UC. However, it is impossible to completely restore the microbiota, and the removal of certain pathogenic bacteria is not sufficient to achieve a good therapeutic effect. Therefore, it is necessary to further understand the molecular basis of host and bacterial interaction and provide a good strategy for the treatment of microbiota in the future.

\section{AUTHOR CONTRIBUTIONS}

S-LZ retrieved and analyzed concerned literatures. S-LZ and $\mathrm{S}-\mathrm{NW}$ wrote the manuscript. C-YM revised the manuscript. All the authors agreed to be accountable for the content of the work.

\section{ACKNOWLEDGMENTS}

This work was supported by grants from the National Natural Science Foundation of China (81730098 and 81130061) and the Shanghai Project (16JC1405100).

9. Faith JJ, Guruge JL, Charbonneau M, Subramanian S, SeedorfH, Goodman AL, et al. The long-term stability of the human gut microbiota. Science (2013) 341:1237439. doi:10.1126/science.1237439

10. Sartor RB. Microbial influences in inflammatory bowel diseases. Gastroenterology (2008) 134:577-94. doi:10.1053/j.gastro.2007.11.059

11. Johansson MEV, Larsson JMH, Hansson GC. The two mucus layers of colon are organized by the MUC2 mucin, whereas the outer layer is a legislator of hostmicrobial interactions. Proc Natl Acad Sci U S A (2011) 108:4659-65. doi:10.1073/ pnas. 1006451107

12. Cario E. Microbiota and innate immunity in intestinal inflammation and neoplasia. Curr Opin Gastroenterol (2013) 29:85-91. doi:10.1097/MOG.0b013e32835a670e

13. Shanahan F. The colonic microbiota in health and disease. Curr Opin Gastroenterol (2013) 29:49-54. doi:10.1097/MOG.0b013e32835a3493

14. Vaishnava S, Yamamoto M, Severson KM, Ruhn KA, Yu X, Koren O, et al. The antibacterial lectin RegIIIgamma promotes the spatial segregation of microbiota and host in the intestine. Science (2011) 334:255-8. doi:10.1126/ science. 1209791

15. Sender R, Fuchs S, Milo R. Revised estimates for the number of human and bacteria cells in the body. PLoS Biol (2016) 14:e1002533. doi:10.1371/journal. pbio. 1002533

16. Frank DN, St Amand AL, Feldman RA, Boedeker EC, Harpaz N, Pace NR. Molecular-phylogenetic characterization of microbial community imbalances in human inflammatory bowel diseases. Proc Natl Acad Sci U S A (2007) 104:13780-5. doi:10.1073/pnas.0706625104 
17. Arumugam M, Raes J, Pelletier E, Le Paslier D, Yamada T, Mende DR, et al. Enterotypes of the human gut microbiome. Nature (2011) 473:174-80. doi:10.1038/nature09944

18. Human Microbiome Project Consortium. Structure, function and diversity of the healthy human microbiome. Nature (2012) 486:207-14. doi:10.1038/ nature 11234

19. Eckburg PB, Bik EM, Bernstein CN, Purdom E, Dethlefsen L, Sargent M, et al. Diversity of the human intestinal microbial flora. Science (2005) 308:1635-8. doi:10.1126/science.1110591

20. Hold GL, Schwiertz A, Aminov RI, Blaut M, Flint HJ. Oligonucleotide probes that detect quantitatively significant groups of butyrate-producing bacteria in human feces. Appl Environ Microbiol (2003) 69:4320-4. doi:10.1128/ AEM.69.7.4320-4324.2003

21. Schwiertz A, Jacobi M, Frick JS, Richter M, Rusch K, Kohler H. Microbiota in pediatric inflammatory bowel disease. J Pediatr (2010) 157:240-4.e1. doi:10.1016/j.jpeds.2010.02.046

22. Suau A, Rochet V, Sghir A, Gramet G, Brewaeys S, Sutren M, et al. Fusobacterium prausnitzii and related species represent a dominant group within the human fecal flora. Syst Appl Microbiol (2001) 24:139-45. doi:10.1078/ 0723-2020-00015

23. Walker AW, Ince J, Duncan SH, Webster LM, Holtrop G, Ze X, et al. Dominant and diet-responsive groups of bacteria within the human colonic microbiota. ISME J (2011) 5:220-30. doi:10.1038/ismej.2010.118

24. Barcenilla A, Pryde SE, Martin JC, Duncan SH, Stewart CS, Henderson C, et al. Phylogenetic relationships of butyrate-producing bacteria from the human gut. Appl Environ Microbiol (2000) 66:1654-61. doi:10.1128/AEM.66.4. 1654-1661.2000

25. Duncan SH, Hold GL, Harmsen HJ, Stewart CS, Flint HJ. Growth requirements and fermentation products of Fusobacterium prausnitzii, and a proposal to reclassify it as Faecalibacterium prausnitzii gen. nov., comb. nov. Int J Syst Evol Microbiol (2002) 52:2141-6. doi:10.1099/00207713-52-6-2141

26. Chen WX, Ren LH, Shi RH. Enteric microbiota leads to new therapeutic strategies for ulcerative colitis. World J Gastroenterol (2014) 20:15657-63. doi:10.3748/wjg.v20.i42.15657

27. Qiu X, Zhang M, Yang X, Hong N, Yu C. Faecalibacterium prausnitzii upregulates regulatory $\mathrm{T}$ cells and anti-inflammatory cytokines in treating TNBS-induced colitis. JCrohns Colitis (2013) 7:e558-68. doi:10.1016/j. crohns.2013.04.002

28. Sokol H, Pigneur B, Watterlot L, Lakhdari O, Bermudez-Humaran LG, Gratadoux JJ, et al. Faecalibacterium prausnitzii is an anti-inflammatory commensal bacterium identified by gut microbiota analysis of Crohn disease patients. Proc Natl Acad Sci U S A (2008) 105:16731-6. doi:10.1073/ pnas.0804812105

29. Sarrabayrouse G, Bossard C, Chauvin JM, Jarry A, Meurette G, Quevrain E, et al. CD4CD8alphaalpha lymphocytes, a novel human regulatory $\mathrm{T}$ cell subset induced by colonic bacteria and deficient in patients with inflammatory bowel disease. PLoS Biol (2014) 12:e1001833. doi:10.1371/journal.pbio.1001833

30. Sokol H, Seksik P, Furet JP, Firmesse O, Nion-Larmurier I, Beaugerie L, et al. Low counts of Faecalibacterium prausnitzii in colitis microbiota. Inflamm Bowel Dis (2009) 15:1183-9. doi:10.1002/ibd.20903

31. Lee T, Clavel T, Smirnov K, Schmidt A, Lagkouvardos I, Walker A, et al. Oral versus intravenous iron replacement therapy distinctly alters the gut microbiota and metabolome in patients with IBD. Gut (2017) 66:863-71. doi:10.1136/ gutjnl-2015-309940

32. Lopez-Siles M, Duncan SH, Garcia-Gil LJ, Martinez-Medina M. Faecalibacterium prausnitzii: from microbiology to diagnostics and prognostics. ISME J (2017) 11:841-52. doi:10.1038/ismej.2016.176

33. Knoll RL, Forslund K, Kultima JR, Meyer CU, Kullmer U, Sunagawa S, et al. Gut microbiota differs between children with inflammatory bowel disease and healthy siblings in taxonomic and functional composition: a metagenomic analysis. Am J Physiol Gastrointest Liver Physiol (2017) 312:G327-39. doi:10.1152/ajpgi.00293.2016

34. Prosberg M, Bendtsen F, Vind I, Petersen AM, Gluud LL. The association between the gut microbiota and the inflammatory bowel disease activity: a systematic review and meta-analysis. Scand J Gastroenterol (2016) 51: 1407-15. doi:10.1080/00365521.2016.1216587

35. Li KY, Wang JL, Wei JP, Gao SY, Zhang YY, Wang LT, et al. Fecal microbiota in pouchitis and ulcerative colitis. World J Gastroenterol (2016) 22:8929-39. doi:10.3748/wjg.v22.i40.8929
36. Magnusson MK, Strid H, Sapnara M, Lasson A, Bajor A, Ung KA, et al. Anti-TNF therapy response in patients with ulcerative colitis is associated with colonic antimicrobial peptide expression and microbiota composition. J Crohns Colitis (2016) 10:943-52. doi:10.1093/ecco-jcc/jjw051

37. Lopez-Siles M, Martinez-Medina M, Suris-Valls R, Aldeguer X, Sabat-Mir M, Duncan SH, et al. Changes in the abundance of Faecalibacterium prausnitzii phylogroups I and II in the intestinal mucosa of inflammatory bowel disease and patients with colorectal cancer. Inflamm Bowel Dis (2016) 22:28-41. doi:10.1097/mib.0000000000000590

38. Yao P, Cui M, Wang H, Gao H, Wang L, Yang T, et al. Quantitative analysis of intestinal flora of Uygur and Han ethnic Chinese patients with ulcerative colitis. Gastroenterol Res Pract (2016) 2016:9186232. doi:10.1155/ 2016/9186232

39. Lopez-Siles M, Martinez-Medina M, Abella C, Busquets D, Sabat-Mir M, Duncan SH, et al. Mucosa-associated Faecalibacterium prausnitzii phylotype richness is reduced in patients with inflammatory bowel disease. Appl Environ Microbiol (2015) 81:7582-92. doi:10.1128/aem.02006-15

40. Wang W, Chen L, Zhou R, Wang X, Song L, Huang S, et al. Increased proportions of Bifidobacterium and the Lactobacillus group and loss of butyrate-producing bacteria in inflammatory bowel disease. J Clin Microbiol (2014) 52:398-406. doi: $10.1128 / \mathrm{jcm} .01500-13$

41. Lopez-Siles M, Martinez-Medina M, Busquets D, Sabat-Mir M, Duncan SH, Flint HJ, et al. Mucosa-associated Faecalibacterium prausnitzii and Escherichia coli co-abundance can distinguish irritable bowel syndrome and inflammatory bowel disease phenotypes. Int J Med Microbiol (2014) 304:464-75. doi:10.1016/j.ijmm.2014.02.009

42. Varela E, Manichanh C, Gallart M, Torrejon A, Borruel N, Casellas F, et al. Colonisation by Faecalibacterium prausnitzii and maintenance of clinical remission in patients with ulcerative colitis. Aliment Pharmacol Ther (2013) 38:151-61. doi:10.1111/apt.12365

43. Kabeerdoss J, Sankaran V, Pugazhendhi S, Ramakrishna BS. Clostridium leptum group bacteria abundance and diversity in the fecal microbiota of patients with inflammatory bowel disease: a case-control study in India. BMC Gastroenterol (2013) 13:20. doi:10.1186/1471-230x-13-20

44. Vermeiren J, Van den Abbeele P, Laukens D, Vigsnaes LK, De Vos M, Boon N, et al. Decreased colonization of fecal Clostridium coccoides/Eubacterium rectale species from ulcerative colitis patients in an in vitro dynamic gut model with mucin environment. FEMS Microbiol Ecol (2012) 79:685-96. doi:10.1111/j.1574-6941.2011.01252.x

45. Louis P, Flint HJ. Diversity, metabolism and microbial ecology of butyrate-producing bacteria from the human large intestine. FEMS Microbiol Lett (2009) 294:1-8. doi:10.1111/j.1574-6968.2009.01514.x

46. Machiels K, Joossens M, Sabino J, De Preter V, Arijs I, Eeckhaut V, et al. A decrease of the butyrate-producing species Roseburia hominis and Faecalibacterium prausnitzii defines dysbiosis in patients with ulcerative colitis. Gut (2014) 63:1275-83. doi:10.7150/ijms.6934

47. Martín R, Chain F, Miquel S, Lu J, Gratadoux JJ, Sokol H, et al. The commensal bacterium Faecalibacterium prausnitzii is protective in DNBS-induced chronic moderate and severe colitis models. Inflamm Bowel Dis (2014) 20:417-30. doi:10.1097/01.mib.0000440815.76627.64

48. Martín R, Miquel S, Chain F, Natividad JM, Jury J, Lu J, et al. Faecalibacterium prausnitzii prevents physiological damages in a chronic low-grade inflammation murine model. BMC Microbiol (2015) 15:67. doi:10.1186/ s12866-015-0400-1

49. Zhang M, Qiu X, Zhang H, Yang X, Hong N, Yang Y, et al. Faecalibacterium prausnitzii inhibits interleukin-17 to ameliorate colorectal colitis in rats. PLoS One (2014) 9:e109146. doi:10.1371/journal.pone.0109146

50. Senok AC, Verstraelen H, Temmerman M, Botta GA. Probiotics for the treatment of bacterial vaginosis. Cochrane Database Syst Rev (2009) (4):CD006289. doi:10.1002/14651858.CD006289.pub2

51. Bien J, Palagani V, Bozko P. The intestinal microbiota dysbiosis and Clostridium difficile infection: is there a relationship with inflammatory bowel disease? Therap Adv Gastroenterol (2013) 6:53-68. doi:10.1177/175 $6283 \times 12454590$

52. Navaneethan U, Venkatesh PG, Shen B. Clostridium difficile infection and inflammatory bowel disease: understanding the evolving relationship. World J Gastroenterol (2010) 16:4892-904. doi:10.3748/wjg.v16.i39.4892

53. Young VB, Hanna PC. Overlapping roles for toxins in Clostridium difficile infection. J Infect Dis (2014) 209:9-11. doi:10.1136/gutjnl-2013-304833 
54. Mabardy A, McCarty J, Hackford A, Dao H. IBD: a growing and vulnerable cohort of hospitalized patients with Clostridium difficile infection. Am Surg (2017) 83:605-9.

55. Singh H, Nugent Z, Yu BN, Lix LM, Targownik LE, Bernstein CN. Higher incidence of Clostridium difficile infection among individuals with inflammatory bowel disease. Gastroenterology (2017) 153:430-8.e2. doi:10.1053/j. gastro.2017.04.044

56. Tang YM, Stone CD. Clostridium difficile infection in inflammatory bowel disease: challenges in diagnosis and treatment. Clin J Gastroenterol (2017) 10:112-23. doi:10.1007/s12328-017-0719-2

57. Rodemann JF, Dubberke ER, Reske KA, Seo DH, Stone CD. Incidence of Clostridium difficile infection in inflammatory bowel disease. Clin Gastroenterol Hepatol (2007) 5:339-44. doi:10.1016/j.cgh.2006.12.027

58. Ananthakrishnan AN, Binion DG. Impact of Clostridium difficile on inflammatory bowel disease. Expert Rev Gastroenterol Hepatol (2010) 4:589-600. doi:10.1586/egh.10.55

59. Dieterle MG, Young VB. Reducing recurrence of C. difficile infection. Cell (2017) 169:375. doi:10.1016/j.cell.2017.03.039

60. Keller JJ, Kuijper EJ. Treatment of recurrent and severe Clostridium difficile infection. Annu Rev Med (2015) 66:373-86. doi:10.1146/annurev-med-070813-114317

61. Gong J, Si W, Forster RJ, Huang R, Yu H, Yin Y, et al. 16S rRNA gene-based analysis of mucosa-associated bacterial community and phylogeny in the chicken gastrointestinal tracts: from crops to ceca. FEMS Microbiol Ecol (2007) 59:147-57. doi:10.1111/j.1574-6941.2006.00193.x

62. Li YN, Huang F, Cheng HJ, Li SY, Liu L, Wang LY. Intestine-derived Clostridium leptum induces murine tolerogenic dendritic cells and regulatory $\mathrm{T}$ cells in vitro. Hum Immunol (2014) 75:1232-8. doi:10.1016/j.humimm.2014.09.017

63. Wexler HM. Bacteroides: the good, the bad, and the nitty-gritty. Clin Microbiol $\operatorname{Rev}$ (2007) 20:593-621. doi:10.1128/CMR.00008-07

64. Xu J, Mahowald MA, Ley RE, Lozupone CA, Hamady M, Martens EC, et al. Evolution of symbiotic bacteria in the distal human intestine. PLoS Biol (2007) 5:e156. doi:10.1371/journal.pbio.0050156

65. Mazmanian SK, Liu CH, Tzianabos AO, Kasper DL. An immunomodulatory molecule of symbiotic bacteria directs maturation of the host immune system. Cell (2005) 122:107-18. doi:10.1016/j.cell.2005.05.007

66. Chiu CC, Ching YH, Wang YC, Liu JY, Li YP, Huang YT, et al. Monocolonization of germ-free mice with Bacteroides fragilis protects against dextran sulfate sodium-induced acute colitis. Biomed Res Int (2014) 2014:675786. doi:10.1155/2014/675786

67. Lopetuso LR, Petito V, Graziani C, Schiavoni E, Paroni Sterbini F, Poscia A, et al. Gut microbiota in health, diverticular disease, irritable bowel syndrome, and inflammatory bowel diseases: time for microbial marker of gastrointestinal disorders? Dig Dis (2017) 36:56-65. doi:10.1159/000477205

68. Zitomersky NL, Atkinson BJ, Franklin SW, Mitchell PD, Snapper SB, Comstock LE, et al. Characterization of adherent bacteroidales from intestinal biopsies of children and young adults with inflammatory bowel disease. PLoS One (2013) 8:e63686. doi:10.1371/journal.pone.0063686

69. Mazmanian SK, Round JL, Kasper DL. A microbial symbiosis factor prevents intestinal inflammatory disease. Nature (2008) 453:620-5. doi:10.1038/ nature 07008

70. Round JL, Mazmanian SK. Inducible Foxp3+ regulatory T-cell development by a commensal bacterium of the intestinal microbiota. Proc Natl Acad Sci US A (2010) 107:12204-9. doi:10.1073/pnas.0909122107

71. Im E, Jung J, Pothoulakis C, Rhee SH. Disruption of Pten speeds onset and increases severity of spontaneous colitis in Il10(-/-) mice. Gastroenterology (2014) 147:667-79.e10. doi:10.1053/j.gastro.2014.05.034

72. Okayasu I, Hatakeyama S, Yamada M, Ohkusa T, Inagaki Y, Nakaya R. A novel method in the induction of reliable experimental acute and chronic ulcerative colitis in mice. Gastroenterology (1990) 98:694-702. doi:10.1016/0016-5085(90)90290-H

73. Kuwahara T, Yamashita A, Hirakawa H, Nakayama H, Toh H, Okada N, et al. Genomic analysis of Bacteroides fragilis reveals extensive DNA inversions regulating cell surface adaptation. Proc Natl Acad Sci U S A (2004) 101:14919-24. doi:10.1073/pnas.0404172101

74. Conte MP, Schippa S, Zamboni I, Penta M, Chiarini F, Seganti L, et al. Gutassociated bacterial microbiota in paediatric patients with inflammatory bowel disease. Gut (2006) 55:1760-7. doi:10.1136/gut.2005.078824

75. Setoyama H, Imaoka A, Ishikawa H, Umesaki Y. Prevention of gut inflammation by Bifidobacterium in dextran sulfate-treated gnotobiotic mice associated with Bacteroides strains isolated from ulcerative colitis patients. Microbes Infect (2003) 5:115-22. doi:10.1016/S1286-4579(02)00080-1

76. Matsuda H, Fujiyama Y, Andoh A, Ushijima T, Kajinami T, Bamba T. Characterization of antibody responses against rectal mucosa-associated bacterial flora in patients with ulcerative colitis. J Gastroenterol Hepatol (2000) 15:61-8. doi:10.1046/j.1440-1746.2000.02045.x

77. Bamba T, Matsuda H, Endo M, Fujiyama Y. The pathogenic role of Bacteroides vulgatus in patients with ulcerative colitis. JGastroenterol (1995) 30 (Suppl 8):45-7.

78. Hansen JJ, Huang Y, Peterson DA, Goeser L, Fan TJ, Chang EB, et al. The colitis-associated transcriptional profile of commensal Bacteroides thetaiotaomicron enhances adaptive immune responses to a bacterial antigen. PLoS One (2012) 7:e42645. doi:10.1371/journal.pone.0042645

79. Hudcovic T, Kozakova H, Kolinska J, Stepankova R, Hrncir T, TlaskalovaHogenova H. Monocolonization with Bacteroides ovatus protects immunodeficient SCID mice from mortality in chronic intestinal inflammation caused by long-lasting dextran sodium sulfate treatment. Physiol Res (2009) 58:101-10.

80. Uronis JM, Muhlbauer M, Herfarth HH, Rubinas TC, Jones GS, Jobin C. Modulation of the intestinal microbiota alters colitis-associated colorectal cancer susceptibility. PLoS One (2009) 4:e6026. doi:10.1371/journal.pone. 0006026

81. Kosek M, Bern C, Guerrant RL. The global burden of diarrhoeal disease, as estimated from studies published between 1992 and 2000. Bull World Health Organ (2003) 81:197-204.

82. Solo-Gabriele HM, Wolfert MA, Desmarais TR, Palmer CJ. Sources of Escherichia coli in a coastal subtropical environment. Appl Environ Microbiol (2000) 66:230-7. doi:10.1128/AEM.66.1.230-237.2000

83. Power ML, Littlefield-Wyer J, Gordon DM, Veal DA, Slade MB. Phenotypic and genotypic characterization of encapsulated Escherichia coli isolated from blooms in two Australian lakes. Environ Microbiol (2005) 7:631-40. doi:10.1111/j.1462-2920.2005.00729.x

84. Lupp C, Robertson ML, Wickham ME, Sekirov I, Champion OL, Gaynor EC, et al. Host-mediated inflammation disrupts the intestinal microbiota and promotes the overgrowth of Enterobacteriaceae. Cell Host Microbe (2007) 2:119-29. doi:10.1016/j.chom.2007.06.010

85. Kolho KL, Korpela K, Jaakkola T, Pichai MV, Zoetendal EG, Salonen A, et al. Fecal microbiota in pediatric inflammatory bowel disease and its relation to inflammation. Am J Gastroenterol (2015) 110:921-30. doi:10.1038/ ajg.2015.149

86. Nagao-Kitamoto H, Shreiner AB, Gillilland MG III, Kitamoto S, Ishii C, Hirayama A, et al. Functional characterization of inflammatory bowel disease-associated gut dysbiosis in gnotobiotic mice. Cell Mol Gastroenterol Hepatol (2016) 2:468-81. doi:10.1016/j.jcmgh.2016.02.003

87. Pilarczyk-Zurek M, Chmielarczyk A, Gosiewski T, Tomusiak A, Adamski P, Zwolinska-Wcislo M, et al. Possible role of Escherichia coli in propagation and perpetuation of chronic inflammation in ulcerative colitis. BMC Gastroenterol (2013) 13:61. doi:10.1186/1471-230X-13-61

88. Sha S, Xu B, Wang X, Zhang Y, Wang H, Kong X, et al. The biodiversity and composition of the dominant fecal microbiota in patients with inflammatory bowel disease. Diagn Microbiol Infect Dis (2013) 75:245-51. doi:10.1016/j. diagmicrobio.2012.11.022

89. Rehman A, Lepage P, Nolte A, Hellmig S, Schreiber S, Ott SJ. Transcriptional activity of the dominant gut mucosal microbiota in chronic inflammatory bowel disease patients. J Med Microbiol (2010) 59:1114-22. doi:10.1099/ jmm.0.021170-0

90. Siczek K, Zatorski H, Chmielowiec-Korzeniowska A, Pulit-Prociak J, Smiech M, Kordek R, et al. Synthesis and evaluation of anti-inflammatory properties of silver nanoparticle suspensions in experimental colitis in mice. Chem Biol Drug Des (2017) 89:538-47. doi:10.1111/cbdd.12876

91. Martinez-Medina M, Aldeguer X, Lopez-Siles M, Gonzalez-Huix F, LopezOliu C, Dahbi G, et al. Molecular diversity of Escherichia coli in the human gut: new ecological evidence supporting the role of adherent-invasive E. coli (AIEC) in Crohn's disease. Inflamm Bowel Dis (2009) 15:872-82. doi:10.1002/ ibd. 20860

92. Martin HM, Campbell BJ, Hart CA, Mpofu C, Nayar M, Singh R, et al. Enhanced Escherichia coli adherence and invasion in Crohn's disease and colon cancer. Gastroenterology (2004) 127:80-93. doi:10.1053/j.gastro. 2004.03.054 
93. Mylonaki M, Rayment NB, Rampton DS, Hudspith BN, Brostoff J. Molecular characterization of rectal mucosa-associated bacterial flora in inflammatory bowel disease. Inflamm Bowel Dis (2005) 11:481-7. doi:10.1097/01. MIB.0000159663.62651.4f

94. Darfeuille-Michaud A, Boudeau J, Bulois P, Neut C, Glasser AL, Barnich N, et al. High prevalence of adherent-invasive Escherichia coli associated with ileal mucosa in Crohn's disease. Gastroenterology (2004) 127:412-21. doi:10.1053/j.gastro.2004.04.061

95. Sokol H, Lepage P, Seksik P, Dore J, Marteau P. Temperature gradient gel electrophoresis of fecal 16S rRNA reveals active Escherichia coli in the microbiota of patients with ulcerative colitis. J Clin Microbiol (2006) 44:3172-7. doi:10.1128/JCM.02600-05

96. Chassaing B, Darfeuille-Michaud A. The commensal microbiota and enteropathogens in the pathogenesis of inflammatory bowel diseases. Gastroenterology (2011) 140:1720-8. doi:10.1053/j.gastro.2011.01.054

97. Martinez-Medina M, Garcia-Gil LJ. Escherichia coli in chronic inflammatory bowel diseases: an update on adherent invasive Escherichia coli pathogenicity. World J Gastrointest Pathophysiol (2014) 5:213-27. doi:10.4291/wjgp. v5.i3.213

98. Low D, Tran HT, Lee IA, Dreux N, Kamba A, Reinecker HC, et al. Chitinbinding domains of Escherichia coli ChiA mediate interactions with intestinal epithelial cells in mice with colitis. Gastroenterology (2013) 145:602-12.e9. doi:10.1053/j.gastro.2013.05.017

99. Morgan XC, Tickle TL, Sokol H, Gevers D, Devaney KL, Ward DV, et al. Dysfunction of the intestinal microbiome in inflammatory bowel disease and treatment. Genome Biol (2012) 13:R79. doi:10.1186/gb-2012-13-9-r79

100. Sartor RB. Therapeutic manipulation of the enteric microflora in inflammatory bowel diseases: antibiotics, probiotics, and prebiotics. Gastroenterology (2004) 126:1620-33. doi:10.1053/j.gastro.2004.03.024

101. Imaoka A, Shima T, Kato K, Mizuno S, Uehara T, Matsumoto S, et al. Antiinflammatory activity of probiotic Bifidobacterium: enhancement of IL-10 production in peripheral blood mononuclear cells from ulcerative colitis patients and inhibition of IL-8 secretion in HT-29 cells. World J Gastroenterol (2008) 14:2511-6. doi:10.3748/wjg.14.2511

102. Jeon SG, Kayama H, Ueda Y, Takahashi T, Asahara T, Tsuji H, et al. Probiotic Bifidobacterium breve induces IL-10-producing $\operatorname{Tr} 1$ cells in the colon. PLoS Pathog (2012) 8:e1002714. doi:10.1371/journal.ppat.1002714

103. Sonnenberg A. Review article: historic changes of Helicobacter pylori-associated diseases. Aliment Pharmacol Ther (2013) 38:329-42. doi:10.3748/wjg. v19.i22.3404

104. Smolka AJ, Backert S. How Helicobacter pylori infection controls gastric acid secretion. J Gastroenterol (2012) 47:609-18. doi:10.1007/s00535-012-0592-1

105. Keenan JI, Beaugie CR, Jasmann B, Potter HC, Collett JA, Frizelle FA. Helicobacter species in the human colon. Colorectal Dis (2010) 12:48-53. doi:10.1111/j.1463-1318.2008.01672.x

106. Kelly SM, Pitcher MC, Farmery SM, Gibson GR. Isolation of Helicobacter pylori from feces of patients with dyspepsia in the United Kingdom. Gastroenterology (1994) 107:1671-4. doi:10.1016/0016-5085(94)90806-0

107. Kabir S. Detection of Helicobacter pylori DNA in feces and saliva by polymerase chain reaction: a review. Helicobacter (2004) 9:115-23. doi:10.1111/j.1083-4389.2004.00207.x

108. Kabir S. Detection of Helicobacter pylori in faeces by culture, PCR and enzyme immunoassay. J Med Microbiol (2001) 50:1021-9. doi:10.1099/00221317-50-12-1021

109. Engler DB, Leonardi I, Hartung ML, Kyburz A, Spath S, Becher B, et al. Helicobacter pylori-specific protection against inflammatory bowel disease requires the NLRP3 inflammasome and IL-18. Inflamm Bowel Dis (2015) 21(4):854-61. doi:10.1097/MIB.0000000000000318

110. Liu JY, Li YP, Huang YT, Chuang HL, Papamichael K, Konstantopoulos P, et al. Helicobacter pylori infection and inflammatory bowel disease: is there a link? Biomed Res Int (2014) 20:6374-85.

111. Yu Q, Zhang S, Li L, Xiong L, Chao K, Zhong B, et al. Enterohepatic Helicobacter species as a potential causative factor in inflammatory bowel disease: a meta-analysis. Medicine (Baltimore) (2015) 94:e1773. doi:10.1097/ md.0000000000001773

112. Ohkusa T, Yoshida T, Sato N, Watanabe S, Tajiri H, Okayasu I. Commensal bacteria can enter colonic epithelial cells and induce proinflammatory cytokine secretion: a possible pathogenic mechanism of ulcerative colitis. J Med Microbiol (2009) 58:535-45. doi:10.1099/jmm.0.005801-0
113. Ohkusa T, Sato N, Ogihara T, Morita K, Ogawa M, Okayasu I. Fusobacterium varium localized in the colonic mucosa of patients with ulcerative colitis stimulates species-specific antibody. J Gastroenterol Hepatol (2002) 17: 849-53. doi:10.1046/j.1440-1746.2002.02834.x

114. Strauss J, Kaplan GG, Beck PL, Rioux K, Panaccione R, Devinney R, et al. Invasive potential of gut mucosa-derived Fusobacterium nucleatum positively correlates with IBD status of the host. Inflamm Bowel Dis (2011) 17:1971-8. doi:10.1002/ibd.21606

115. Tahara T, Shibata T, Kawamura T, Okubo M, Ichikawa Y, Sumi K, et al. Fusobacterium detected in colonic biopsy and clinicopathological features of ulcerative colitis in Japan. Dig Dis Sci (2015) 60:205-10. doi:10.1007/ s10620-014-3316-y

116. Bashir A, Miskeen AY, Hazari YM, Asrafuzzaman S, Fazili KM. Fusobacterium nucleatum, inflammation, and immunity: the fire within human gut. Tumour Biol (2016) 37:2805-10. doi:10.1007/s13277-015-4724-0

117. Lidar M, Langevitz P, Shoenfeld Y. The role of infection in inflammatory bowel disease: initiation, exacerbation and protection. Isr Med Assoc J (2009) 11:558-63.

118. Chen W, Li D, Paulus B, Wilson I, Chadwick VS. Detection of Listeria monocytogenes by polymerase chain reaction in intestinal mucosal biopsies from patients with inflammatory bowel disease and controls. J Gastroenterol Hepatol (2000) 15:1145-50. doi:10.1046/j.1440-1746.2000.02331.x

119. Zwolinska-Wcislo M, Brzozowski T, Budak A, Kwiecien S, Sliwowski Z, Drozdowicz D, et al. Effect of Candida colonization on human ulcerative colitis and the healing of inflammatory changes of the colon in the experimental model of colitis ulcerosa. J Physiol Pharmacol (2009) 60:107-18.

120. Zwolinska-Wcislo M, Budak A, Trojanowska D, Mach T, Rudnicka-Sosin L, Galicka-Latala D, et al. [The influence of Candida albicans on the course of ulcerative colitis]. Przegl Lek (2006) 63:533-8.

121. Conforti-Andreoni C, Ricciardi-Castagnoli P, Mortellaro A. The inflammasomes in health and disease: from genetics to molecular mechanisms of autoinflammation and beyond. Cell Mol Immunol (2011) 8:135-45. doi:10.1038/cmi.2010.81

122. Zambetti LP, Laudisi F, Licandro G, Ricciardi-Castagnoli P, Mortellaro A. The rhapsody of NLRPs: master players of inflammation... and a lot more. Immunol Res (2012) 53:78-90. doi:10.1007/s12026-012-8272-Z

123. Zhang Z, Shen P, Lu X, Li Y, Liu J, Liu B, et al. In vivo and in vitro study on the efficacy of terpinen-4-ol in dextran sulfate sodium-induced mice experimental colitis. Front Immunol (2017) 8:558. doi:10.3389/fimmu.2017.00558

124. Dupaul-Chicoine J, Yeretssian G, Doiron K, Bergstrom KS, McIntire CR, LeBlanc PM, et al. Control of intestinal homeostasis, colitis, and colitis-associated colorectal cancer by the inflammatory caspases. Immunity (2010) 32:367-78. doi:10.1016/j.immuni.2010.02.012

125. Hirota SA, Ng J, Lueng A, Khajah M, Parhar K, Li Y, et al. NLRP3 inflammasome plays a key role in the regulation of intestinal homeostasis. Inflamm Bowel Dis (2011) 17:1359-72. doi:10.1002/ibd.21478

126. Bauer C, Duewell P, Mayer C, Lehr HA, Fitzgerald KA, Dauer M, et al. Colitis induced in mice with dextran sulfate sodium (DSS) is mediated by the NLRP3 inflammasome. Gut (2010) 59:1192-9. doi:10.1136/gut.2009.197822

127. Allen IC, TeKippe EM, Woodford RM, Uronis JM, Holl EK, Rogers AB, et al. The NLRP3 inflammasome functions as a negative regulator of tumorigenesis during colitis-associated cancer. J Exp Med (2010) 207:1045-56. doi:10.1084/ jem. 20100050

128. Elinav E, Strowig T, Kau AL, Henao-Mejia J, Thaiss CA, Booth CJ, et al. NLRP6 inflammasome regulates colonic microbial ecology and risk for colitis. Cell (2011) 145:745-57. doi:10.1016/j.cell.2011.04.022

129. Wlodarska M, Thaiss CA, Nowarski R, Henao-Mejia J, Zhang JP, Brown EM, et al. NLRP6 inflammasome orchestrates the colonic host-microbial interface by regulating goblet cell mucus secretion. Cell (2014) 156:1045-59. doi:10.1016/j.cell.2014.01.026

130. Allen IC, Wilson JE, Schneider M, Lich JD, Roberts RA, Arthur JC, et al. NLRP12 suppresses colon inflammation and tumorigenesis through the negative regulation of noncanonical NF-kappaB signaling. Immunity (2012) 36:742-54. doi:10.1016/j.immuni.2012.03.012

131. Zaki MH, Vogel P, Malireddi RK, Body-Malapel M, Anand PK, Bertin J, et al. The NOD-like receptor NLRP12 attenuates colon inflammation and tumorigenesis. Cancer Cell (2011) 20:649-60. doi:10.1016/j.ccr.2011.10.022

132. Berridge MJ. Vitamin D and depression: cellular and regulatory mechanisms. Pharmacol Rev (2017) 69:80-92. doi:10.1124/pr.116.013227 
133. Al Mheid I, Quyyumi AA. Vitamin D and cardiovascular disease controversy unresolved. J Am Coll Cardiol (2017) 70:89-100. doi:10.1016/j. jacc.2017.05.031

134. Feldman D, Krishnan AV, Swami S, Giovannucci E, Feldman BJ. The role of vitamin D in reducing cancer risk and progression. Nat Rev Cancer (2014) 14:342-57. doi:10.1038/nrc3691

135. Haussler MR, Whitfield GK, Haussler CA, Hsieh JC, Thompson PD, Selznick SH, et al. The nuclear vitamin $\mathrm{D}$ receptor: biological and molecular regulatory properties revealed. J Bone Miner Res (1998) 13:325-49. doi:10.1359/ jbmr.1998.13.3.325

136. Gombart AF, Borregaard N, Koeffler HP. Human cathelicidin antimicrobial peptide (CAMP) gene is a direct target of the vitamin $\mathrm{D}$ receptor and is strongly up-regulated in myeloid cells by 1,25 -dihydroxyvitamin D3. FASEB J (2005) 19:1067-77. doi:10.1096/fj.04-3284com

137. Kamen DL, Tangpricha V. Vitamin D and molecular actions on the immune system: modulation of innate and autoimmunity. J Mol Med (Berl) (2010) 88:441-50. doi:10.1007/s00109-010-0590-9

138. Kong J, Zhang Z, Musch MW, Ning G, Sun J, Hart J, et al. Novel role of the vitamin $D$ receptor in maintaining the integrity of the intestinal mucosal barrier. Am J Physiol Gastrointest Liver Physiol (2008) 294:G208-16. doi:10.1152/ ajpgi.00398.2007

139. Waterhouse JC, Perez TH, Albert PJ. Reversing bacteria-induced vitamin D receptor dysfunction is key to autoimmune disease. Ann N Y Acad Sci (2009) 1173:757-65. doi:10.1111/j.1749-6632.2009.04637.x

140. Wu S, Liao AP, Xia Y, Li YC, Li JD, Sartor RB, et al. Vitamin D receptor negatively regulates bacterial-stimulated NF-kappaB activity in intestine. Am J Pathol (2010) 177:686-97. doi:10.2353/ajpath.2010.090998

141. Abreu MT, Kantorovich V, Vasiliauskas EA, Gruntmanis U, Matuk R, Daigle K, et al. Measurement of vitamin D levels in inflammatory bowel disease patients reveals a subset of Crohn's disease patients with elevated 1,25dihydroxyvitamin D and low bone mineral density. Gut (2004) 53:1129-36. doi:10.1136/gut.2003.036657

142. Pappa HM, Grand RJ, Gordon CM. Report on the vitamin D status of adult and pediatric patients with inflammatory bowel disease and its significance for bone health and disease. Inflamm Bowel Dis (2006) 12:1162-74. doi:10.1097/01.mib.0000236929.74040.b0

143. Sentongo TA, Semaeo EJ, Stettler N, Piccoli DA, Stallings VA, Zemel BS. Vitamin D status in children, adolescents, and young adults with Crohn disease. Am J Clin Nutr (2002) 76:1077-81.

144. Ooi JH, Li Y, Rogers CJ, Cantorna MT. Vitamin D regulates the gut microbiome and protects mice from dextran sodium sulfate-induced colitis. J Nutr (2013) 143:1679-86. doi:10.3945/jn.113.180794

145. Cantorna MT, McDaniel K, Bora S, Chen J, James J. Vitamin D, immune regulation, the microbiota, and inflammatory bowel disease. Exp Biol Med (Maywood) (2014) 239:1524-30. doi:10.1177/1535370214523890

146. Wang J, Thingholm LB, Skieceviciene J, Rausch P, Kummen M, Hov JR, et al. Genome-wide association analysis identifies variation in vitamin D receptor and other host factors influencing the gut microbiota. Nat Genet (2016) 48:1396-406. doi:10.1038/ng.3695

147. Chen SW, Wang PY, Zhu J, Chen GW, Zhang JL, Chen ZY, et al. Protective effect of 1,25-dihydroxyvitamin d3 on lipopolysaccharide-induced intestinal epithelial tight junction injury in caco-2 cell monolayers. Inflammation (2015) 38:375-83. doi:10.1007/s10753-014-0041-9

148. Jahani R, Fielding KA, Chen J, Villa CR, Castelli LM, Ward WE, et al. Low vitamin $\mathrm{D}$ status throughout life results in an inflammatory prone status but does not alter bone mineral or strength in healthy 3-month-old CD-1 male mice. Mol Nutr Food Res (2014) 58:1491-501. doi:10.1002/mnfr.201300928

149. Jin D, Wu S, Zhang YG, Lu R, Xia Y, Dong H, et al. Lack of vitamin D receptor causes dysbiosis and changes the functions of the murine intestinal microbiome. Am J Physiol Gastrointest Liver Physiol (2015) 37:996-1009.e1007. doi:10.1152/ajpgi.00105.2015

150. Ryz NR, Patterson SJ, Zhang Y, Ma C, Huang T, Bhinder G, et al. Active vitamin D (1,25-dihydroxyvitamin D3) increases host susceptibility to Citrobacter rodentium by suppressing mucosal Th17 responses. Am J Physiol Gastrointest Liver Physiol (2012) 303:G1299-311. doi:10.1152/ajpgi.00320.2012
151. Assa A, Vong L, Pinnell LJ, Rautava J, Avitzur N, Johnson-Henry KC, et al. Vitamin D deficiency predisposes to adherent-invasive Escherichia coliinduced barrier dysfunction and experimental colonic injury. Inflamm Bowel Dis (2015) 21:297-306. doi:10.1097/mib.0000000000000282

152. Yu S, Bruce D, Froicu M, Weaver V, Cantorna MT. Failure of T cell homing, reduced $\mathrm{CD} 4 / \mathrm{CD} 8$ alphaalpha intraepithelial lymphocytes, and inflammation in the gut of vitamin D receptor KO mice. Proc Natl Acad Sci U S A (2008) 105:20834-9. doi:10.1073/pnas.0808700106

153. Wu S, Yoon S, Zhang YG, Lu R, Xia Y, Wan J, et al. Vitamin D receptor pathway is required for probiotic protection in colitis. Am J Physiol Gastrointest Liver Physiol (2015) 309:G341-9. doi:10.1021/acs.jafc.5b05415

154. Piodi LP, Bardella M, Rocchia C, Cesana BM, Baldassarri A, Quatrini M. Possible protective effect of 5-aminosalicylic acid on Helicobacter pylori infection in patients with inflammatory bowel disease. J Clin Gastroenterol (2003) 36:22-5. doi:10.1097/00004836-200301000-00008

155. Billiau A, Matthys P. Interferon-gamma: a historical perspective. Cytokine Growth Factor Rev (2009) 20:97-113. doi:10.1016/j.cytogfr.2009.02.004

156. Huttenhower C, Kostic AD, Xavier RJ. Inflammatory bowel disease as a model for translating the microbiome. Immunity (2014) 40:843-54. doi:10.1016/j. immuni.2014.05.013

157. Carvalho FA, Nalbantoglu I, Ortega-Fernandez S, Aitken JD, Su Y, Koren O, et al. Interleukin-1beta (IL-1beta) promotes susceptibility of toll-like receptor 5 (TLR5) deficient mice to colitis. Gut (2012) 61:373-84. doi:10.1136/ gut.2011.240556

158. Demon D, Kuchmiy A, Fossoul A, Zhu Q, Kanneganti TD, Lamkanfi M. Caspase-11 is expressed in the colonic mucosa and protects against dextran sodium sulfate-induced colitis. Mucosal Immunol (2014) 7:1480-91. doi:10.1038/mi.2014.36

159. Yang JY, Kim MS, Kim E, Cheon JH, Lee YS, Kim Y, et al. Enteric viruses ameliorate gut inflammation via toll-like receptor 3 and toll-like receptor 7-mediated interferon-beta production. Immunity (2016) 44:889-900. doi:10.1016/j.immuni.2016.03.009

160. Nishino J, Yamashita K, Hashiguchi H, Fujii H, Shimazaki T, Hamada H. Meteorin: a secreted protein that regulates glial cell differentiation and promotes axonal extension. EMBO J (2004) 23:1998-2008. doi:10.1038/ sj.emboj.7600202

161. Zheng SL, Li ZY, Song J, Liu JM, Miao CY. Metrnl: a secreted protein with new emerging functions. Acta Pharmacol Sin (2016) 37:571-9. doi:10.1038/ aps.2016.9

162. Jorgensen JR, Fransson A, Fjord-Larsen L, Thompson LH, Houchins JP, Andrade N, et al. Cometin is a novel neurotrophic factor that promotes neurite outgrowth and neuroblast migration in vitro and supports survival of spiral ganglion neurons in vivo. Exp Neurol (2012) 233:172-81. doi:10.1016/j. expneurol.2011.09.027

163. Li ZY, Zheng SL, Wang P, Xu TY, Guan YF, Zhang YJ, et al. Subfatin is a novel adipokine and unlike meteorin in adipose and brain expression. CNS Neurosci Ther (2014) 20:344-54. doi:10.1111/cns.12219

164. Li ZY, Song J, Zheng SL, Fan MB, Guan YF, Qu Y, et al. Adipocyte Metrnl antagonizes insulin resistance through PPAR gamma signaling. Diabetes (2015) 64:4011-22. doi:10.2337/db15-0274

165. Li ZY, Fan MB, Zhang SL, Qu Y, Zheng SL, Song J, et al. Intestinal Metrnl released into the gut lumen acts as a local regulator for gut antimicrobial peptides. Acta Pharmacol Sin (2016) 37:1458-66. doi:10.1038/aps.2016.70

Conflict of Interest Statement: The authors declare that there is no conflict of interests regarding the publication of this paper.

The reviewer KL and handling editor declared their shared affiliation.

Copyright (c) 2017 Zhang, Wang and Miao. This is an open-access article distributed under the terms of the Creative Commons Attribution License (CC BY). The use, distribution or reproduction in other forums is permitted, provided the original author(s) or licensor are credited and that the original publication in this journal is cited, in accordance with accepted academic practice. No use, distribution or reproduction is permitted which does not comply with these terms. 